\title{
PEMANFAATAN ENERGI SURYA
}

\author{
Oleh \\ Gede Widayana \\ Jurusan Pendidikan Teknik Mesin, FTK, UNDIKSHA
}

\begin{abstract}
ABSTRAK
Energi pada saat ini mempunyai peranan yang sangat penting dalam kehidupan manusia. Selama ini penyangga utama kebutuhan energi masih mengandalkan minyak bumi .Sementara itu tidak dapat dihindarkan bahwa minyak bumi semakin langka dan mahal harganya. Dengan keadaan semakin menipisnya sumber energi fosil tersebut, di dunia sekarang ini terjadi pergeseran dari penggunaan sumber energi tak terbaharui menuju sumber energi terbaharui. Dari sekian banyak sumber energi terbahurui penggunaan energi melalui solar cell / sel surya merupakan alternatif yang paling potensial untuk diterapkan di wilayah Indonesia. Energi surya merupakan salah satu energi yang sedang giat dikembangkan saat ini oleh pemerintah Indonesia karena sebagai negara tropis, Indonesia mempunyai potensi energi surya yang cukup besar. Energi surya adalah sangat luar biasa karena tidak bersifat polutif, tidak dapat habis, dapat dipercaya dan tidak membeli. Ada banyak cara untuk memanfaatkan energi dari matahari.Istilah "tenaga surya" mempunyai arti mengubah sinar matahari secara langsung menjadi panas atau energi listrik untuk kegunaan kita. Dua tipe dasar tenaga matahari adalah "sinar matahari" dan "photovoltaic" (photo- cahaya, voltaic=tegangan). Photovoltaic tenaga matahari melibatkan pembangkit listrik dari cahaya. Rahasia dari proses ini adalah penggunaan bahan semi konduktor yang dapat disesuaikan untuk melepas elektron, pertikel bermuatan negative yang membentuk dasar listrik. Untuk memanfaatkan potensi energi surya tersebut, ada 2 (dua) macam teknologi yang sudah diterapkan, yaitu:Teknologi energi surya fotovoltaik dan Teknologi energi surya termal.
\end{abstract}

Kata-kata kunci : Energi surya, solar cell, fotovoltaik, surya termal.

\begin{abstract}
Energy at the moment have the very important role in human life. During the time especial prop of requirement energy still rely on the petroleum . Meanwhile cannot be obviated that scarce petroleum progressively costly. With the circumstance progressively attenuate the source fossil energy the world is happened by the friction from use of source energy do not be updated to go to the source energy updated. Solar energy used represent the most potential alternative to be applied in Indonesia region. Solar energy represent one of energy which developed impetous medium in this time by Indonesia government because as tropical state. Indonesia have the big enough potency solar energy. Solar energy is
\end{abstract}


very extraordinary because do not have the character of the polutif, cannot used up, reliably and do not buy. There is a lot of way of to exploit the Solar energy. Solar energy having meaning alter the sunshine directly become the heat or energi electrics for the usefulness of our. Two elementary type of solar energy is " sunshine" and "photovoltaic". Photovoltaic of solar energy entangle the power station from light. Secret from this process is semi substance use conductor which can be accomodated tobe free of electron. To exploit the the potency Solar energy, there is two of kinds of applied technology, photovoltaic technology and termal technology.

Keywords : Solar energy, solar fuel cell, photovoltaic, solar termal.

\section{PENDAHULUAN}

Energi pada saat ini mempunyai peranan yang sangat penting dalam kehidupan manusia. Energi merupakan pendukung bagi kegiatan ekonomi nasional dan dipakai sebagai alat untuk mencapai tujuan sosial, ekonomi, dan lingkungan .

Selama ini penyangga utama kebutuhan energi. masih mengandalkan minyak bumi .Sementara itu tidak dapat dihindarkan bahwa minyak bumi semakin langka dan mahal harganya. Cadangan sumber energi fosil di seluruh dunia terhitung sejak 2002 yaitu 40 tahun untuk minyak, 60 tahun untuk gas alam, dan 200 tahun untuk batu bara. Dengan keadaan semakin menipisnya sumber energi fosil tersebut, di dunia sekarang ini terjadi pergeseran dari penggunaan sumber energi tak terbaharui menuju sumber energi terbaharui. Potensi energi terbarukan, seperti: biomassa, panas bumi, energi surya, energi air, energi angin ,energi samudera,hydro power sampai saat ini belum banyak dimanfaatkan, padahal potensi energi terbarukan ini sangatlah besar khususnya di Indonesia.Dari sekian banyak sumber energi terbahurui seperti diatas penggunaan energi melalui solar cell / sel surya merupakan alternatif yang paling potensial untuk diterapkan di wilayah Indonesia. 


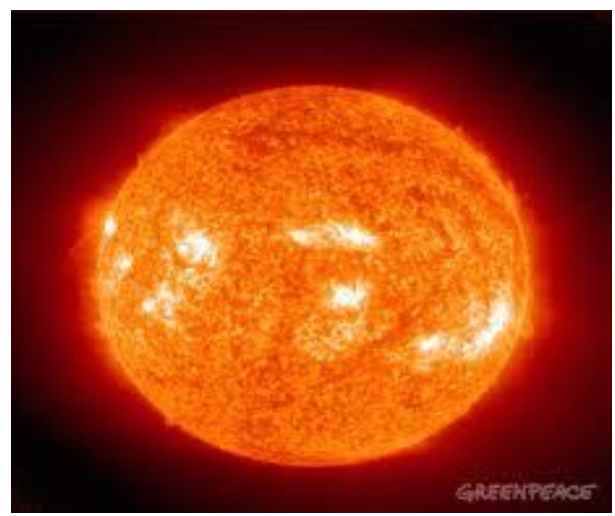

Gambar.1. Matahari

Energi surya merupakan salah satu energi yang sedang giat dikembangkan saat ini oleh pemerintah Indonesia karena sebagai negara tropis, Indonesia mempunyai potensi energi surya yang cukup besar. Berdasarkan data penyinaran matahari yang dihimpun dari 18 lokasi di Indonesia, radiasi surya di Indonesia dapat diklasifikasikan berturut-turut sebagai berikut: untuk kawasan barat dan timur Indonesia dengan distribusi penyinaran di Kawasan Barat Indonesia (KBI) sekitar 4,5 kWh/m 2 /hari dengan variasi bulanan sekitar 10\%; dan di Kawasan Timur Indonesia (KTI) sekitar 5,1 kWh/m 2 /hari dengan variasi bulanan sekitar $9 \%$. Dengan demikian, potesi penyinaran matahari rata-rata Indonesia sekitar $4,8 \mathrm{kWh} / \mathrm{m}$ 2 /hari dengan variasi bulanan sekitar 9\%.Matahari adalah sumber energi utama yang memancarkan energi yang luar biasa besarnya ke permukaan bumi. Pada keadaan cuaca cerah, permukaan bumi menerima sekitar 1000 watt energi matahari per-meter persegi. Kurang dari $30 \%$ energi tersebut dipantulkan kembali ke angkasa, 47\% dikonversikan menjadi panas, $23 \%$ digunakan untuk seluruh sirkulasi kerja yang terdapat di atas permukaan bumi, sebagaian kecil 0,25\% ditampung angin, gelombang dan arus dan masih ada bagian yang sangat kecil 0,025\% disimpan melalui proses fotosintesis di dalam tumbuh-tumbuhan yang akhirnya digunakan dalam proses pembentukan batu bara dan minyak bumi (bahan bakar fosil, proses fotosintesis yang memakan jutaan tahun) yang saat ini digunakan secara ekstensif dan eksploratif bukan hanya untuk bahan bakar tetapi juga untuk bahan pembuat plastik, formika, bahan sintesis lainnya.Sehingga bisa dikatakan bahwa 
sumber segala energi adalah energi surya. Energi surya adalah sangat luar biasa karena tidak bersifat polutif, tidak dapat habis, dapat dipercaya dan tidak membeli. Kejelekannya dari energi surya ini adalah sangat halus dan tidak konstan. Arus energi surya yang rendah mengakibatkan dipakainya system dan kolektor yang luas permukaannya besar untuk mengumpul dan mengkonsentrasikan energi itu. Sistem kolektor ini berharga cukup mahal dan ada masalah lagi bahwa system-sistem di bumi tidak dapat diharapkan akan menerima persediaan yang terus menerus dari energy surya. Hal ini berarti diperlukan semacam system penyimpanan energi atau konversi lain diperlukan untuk menyimpan energi pada malam hari serta pada saat cuaca mendung.

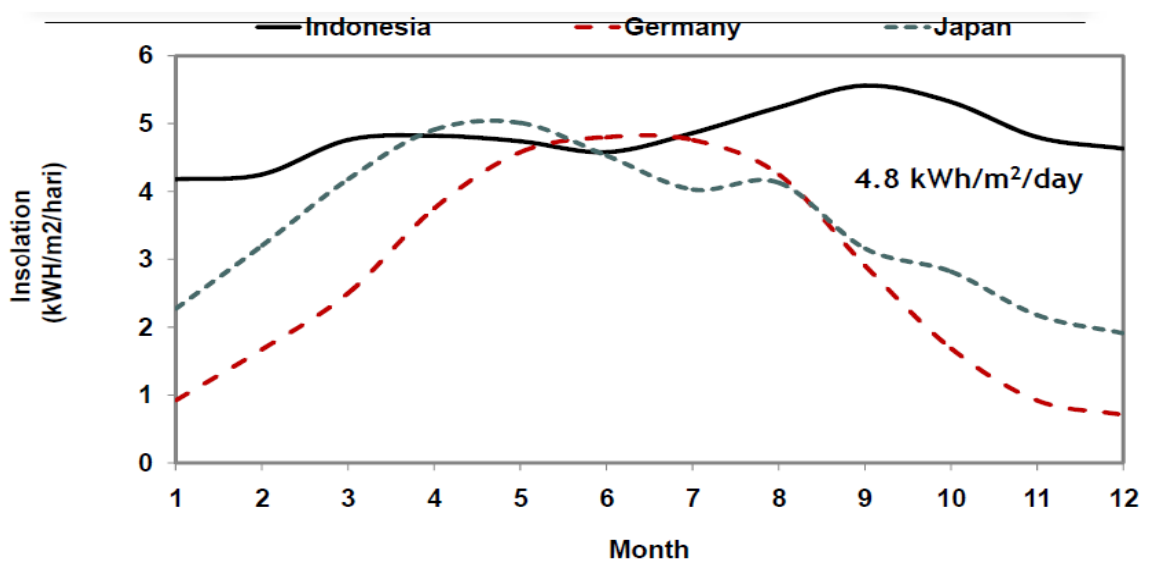

Monthly Average Insolation (NASA 1985 - 2007)

Gambar 2. Grafik Distribusi Penyinaran di Indonesia

Energi surya atau matahari telah dimanfaatkan di banyak belahan dunia dan jika dieksplotasi dengan tepat, energi ini berpotensi mampu menyediakan kebutuhan konsumsi energi dunia saat ini dalam waktu yang lebih lama. Matahari dapat digunakan secara langsung untuk memproduksi listrik atau untuk memanaskan bahkan untuk mendinginkan. Potensi masa depan energi surya hanya dibatasi oleh keinginan kita untuk menangkap kesempatan. 


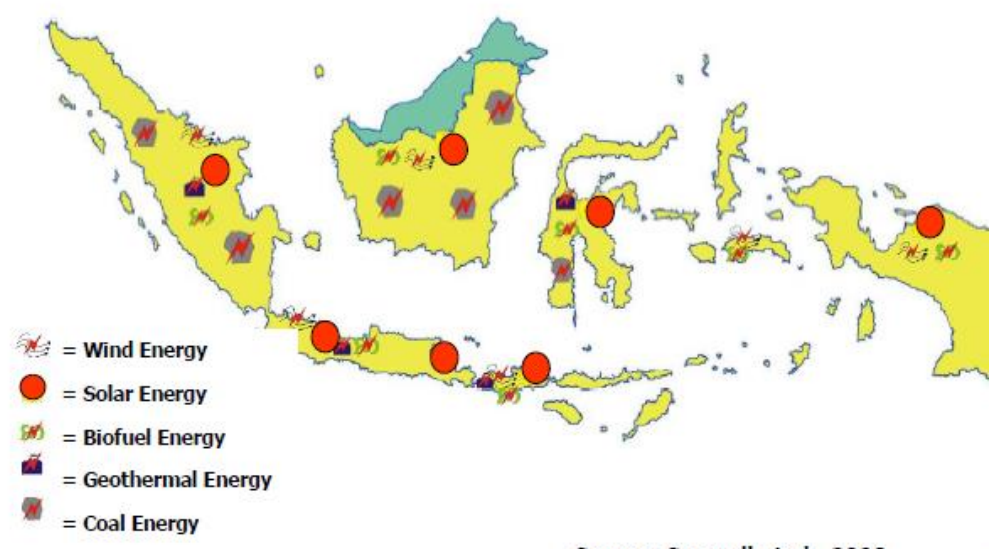

Source: Susandi et al., 2008

Gambar 3. Potensi Solar Energi di Indonesia

\section{PEMBAHASAN}

Ada banyak cara untuk memanfaatkan energi dari matahari. Tumbuhan mengubah sinar matahari menjadi energi kimia dengan menggunakan fotosintesis. Kita memanfaatkan energi ini dengan memakan dan membakar kayu. Bagimanapun, istilah "tenaga surya" mempunyai arti mengubah sinar matahari secara langsung menjadi panas atau energi listrik untuk kegunaan kita. Dua tipe dasar tenaga matahari adalah "sinar matahari" dan "photovoltaic" (photo- cahaya, voltaic=tegangan). Photovoltaic tenaga matahari melibatkan pembangkit listrik dari cahaya. Rahasia dari proses ini adalah penggunaan bahan semi konduktor yang dapat disesuaikan untuk melepas elektron, pertikel bermuatan negative yang membentuk dasar listrik.

Untuk memanfaatkan potensi energi surya tersebut, ada 2 (dua) macam teknologi yang sudah diterapkan, yaitu:

1. Teknologi energi surya fotovoltaik,

Energi surya fotovoltaik digunakan untuk memenuhi kebutuhan listrik, pompa air, televisi, telekomunikasi, dan lemari pendingin di Puskesmas dengan kapasitas total $\pm 6 \mathrm{MW}$.

2. Teknologi energi surya termal, 
Energi surya termal pada umumnya digunakan untuk memasak (kompor surya), mengeringkan hasil pertanian (perkebunan, perikanan, kehutanan, tanaman pangan) dan memanaskan air.

\subsection{Teknologi Energi Surya Fotovoltaik}

Salah satu cara penyediaan energi listrik alternatif yang siap untuk diterapkan secara masal pada saat ini adalah menggunakan suatu sistem teknologi yang diperkenalkan sebagai Sistem Energi Surya Fotovoltaik (SESF) atau secara umum dikenal sebagai Pembangkit Listrik Tenaga Surya Fotovoltaik (PLTS Fotovoltaik). Sebutan SESF merupakan istilah yang telah dibakukan oleh pemerintah yang digunakan untuk mengidentifikasikan suatu sistem pembangkit energi yang memanfaatkan energi matahari dan menggunakan teknologi fotovoltaik. Dibandingkan energi listrik konvensional pada umumnya, SESF terkesan rumit, mahal dan sulit dioperasikan. Namun dari pengalaman lebih dari 15 tahun operasional di beberapa kawasan di Indonesia, SESF merupakan suatu sistem yang mudah didalam pengoperasiannya, handal, serta memerlukan biaya pemeliharaan dan operasi yang rendah menjadikan SESF mampu bersaing dengan teknologi konvensional pada sebagian besar kondisi wilayah Indonesia yang terdiri atas pulau - pulau kecil yang tidak terjangkau oleh jaringan PLN dan tergolong sebagai kawasan terpencil.

Selain itu SESF merupakan suatu teknologi yang bersih dan tidak mencemari lingkungan. Beberapa kondisi yang sesuai untuk penggunaan SESF antara lain pada pemukiman desa terpencil, lokasi transmigrasi, perkebunan, nelayan dan lain sebagainya, baik untuk penerangan rumah maupun untuk fasilitas umum. Akan tetapi sesuai dengan perkembangan jaman, pada saat ini di negara-negara maju penerapan SESF telah banyak digunakan untuk suplai energi listrik di gedunggedung dan perumahan di kota-kota besar.

Pada umumnya modul fotovoltaik dipasarkan dengan kapasitas 50 Wattpeak (Wp) atau kelipatannya. Unit satuan Watt-peak adalah satuan daya (Watt) yang dapat dibangkitkan oleh modul fotovoltaik dalam keadaan standar uji (Standard Test 
Condition - STC).Efisiensi pembangkitan energi listrik yang dihasilkan modul fotovoltaik pada skala komersial saat ini adalah sekitar $14-15 \%$.

Komponen utama suatu SESF adalah sel fotovoltaik yang mengubah penyinaran/radiasi matahari menjadi listrik secara langsung (direct conversion). Teknologi sel fotovoltaik yang banyak dikembangkan dewasa ini pada umumnya merupakan jenis teknologi kristal yang dibuat dengan bahan baku berbasis silikon. Produk akhir dari modul fotovoltaik menyerupai bentuk lembaran kaca dengan ketebalan sekitar 6 - 8 milimeter. Kemudian ada Balance of System (BOS) yang meliputi controller, inverter, kerangka modul,peralatan listrik, seperti kabel, stop kontak, dan lain-lain. Ada juga unit penyimpan energi (baterai) dan peralatan penunjang lain seperti inverter, sistem terpusat, sistem hibrid, dan lain-lain.
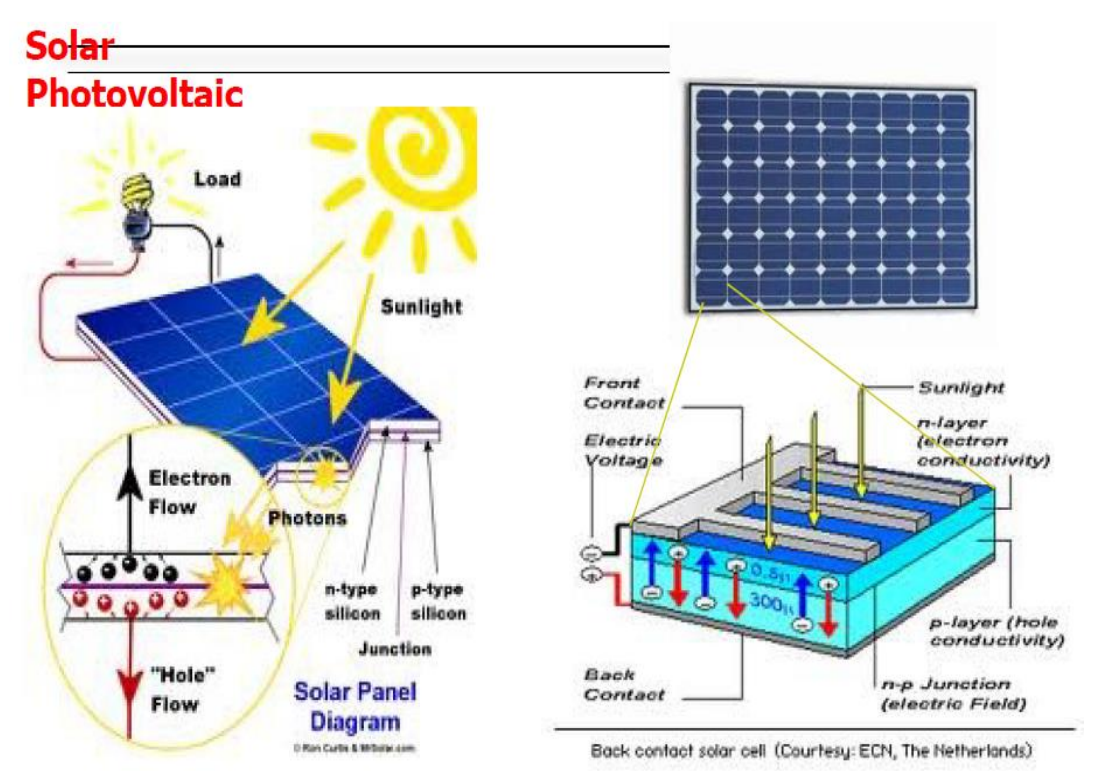

Gambar 4. Skema Sistem Solar Fotovoltaik

\subsection{Teknologi Energi Surya Termal}

Selama ini, pemanfaatan energi surya termal di Indonesia masih dilakukan secara tradisional. Para petani dan nelayan di Indonesia memanfaatkan energi surya untuk mengeringkan hasil pertanian dan perikanan secara langsung. Berbagai teknologi pemanfaatan energi surya termal untuk aplikasi skala rendah (temperatur 
kerja lebih kecil atau hingga 60 o C) dan skala menengah (temperatur kerja antara 60 hingga 120 o C) telah dikuasai dari rancang-bangun, konstruksi hingga manufakturnya secara nasional. Secara umum, teknologi surya termal yang kini dapat dimanfaatkan termasuk dalam teknologi sederhana hingga madya. Beberapa teknologi untuk aplikasi skala rendah dapat dibuat oleh bengkel pertukangan kayu/besi biasa. Untuk aplikasi skala menengah dapat dilakukan oleh industri manufaktur nasional.

Beberapa peralatan yang telah yang mengguanakan energy surya termal seperti sistem atau unit berikut:

- Pengering pasca panen .

- Pemanas air domestic.

- Pemasak/oven.

- Pompa air (dengan Siklus Rankine dan fluida kerja Isopentane ).

- Penyuling air ( Solar Distilation/Still ).

- Pendingin (radiatif, absorpsi, evaporasi, termoelektrik, kompressip, tipe jet).

- Sterilisator surya.

- Pembangkit listrik dengan menggunakan konsentrator dan fluida kerja dengan titik didih rendah.

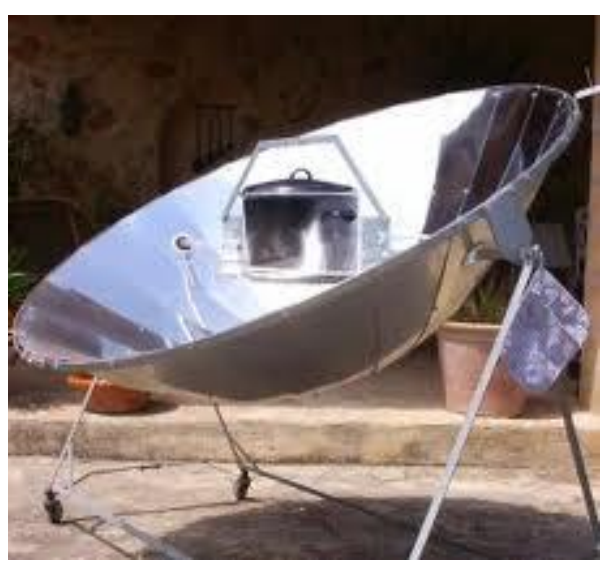

Gambar 5. Kompor Surya 


\subsection{Peluang Pemanfaatan Energi Surya Termal}

Prospek teknologi energi surya termal cukup besar, terutama untuk mendukung peningkatan kualitas pasca-panen komoditi pertanian, untuk bangunan komersial atau perumahan di perkotaan. Prospek pemanfaatannya dalam sektorsektor masyarakat, yaitu:

a. Industri, khususnya agro-industri dan industri pedesaan, yaitu untuk penanganan pasca-panen hasil-hasil pertanian, seperti: pengeringan (komoditi pangan, perkebunan, perikanan/peternakan, kayu olahan) dan juga pendinginan (ikan, buah dan sayuran).

b. Bangunan komersial atau perkantoran, yaitu: untuk pengkondisian ruangan ( Solar Passive Building, AC) dan pemanas air.

c. Rumah tangga, seperti: untuk pemanas air dan oven/ cooker.

d. PUSKESMAS terpencil di pedesaan, yaitu: untuk sterilisator, refrigerator vaksin dan pemanas air.

\section{PENUTUP}

Dari uraian di atas, dapat diambil kesimpulan yaitu :

1. Energi surya atau matahari telah dimanfaatkan di banyak belahan dunia dan jika dieksplotasi dengan tepat, energi ini berpotensi mampu menyediakan kebutuhan konsumsi energi dunia saat ini dalam waktu yang lebih lama.

2. Untuk memanfaatkan potensi energi surya tersebut, ada 2 (dua) macam teknologi yang sudah diterapkan, yaitu Teknologi Energi Surya Fotovoltaik dan Teknologi Energi Surya Termal.

\section{DAFTAR PUSTAKA}

Amien Rahardjo, Herlina dan Husni Safruddin, 2008." Optimalisasi Pemanfaatan Sel Surya Pada Bangunan Komersial Secara Terintegrasi Sebagai Bangunan Hemat Energi “, Lampung, Universitas Lampung.

Archie W Culp, Darwin Sitompul, 2010, Prinsip-Prinsip Konversi Energi, Jakarta, Erlangga. 
Jusuf Tedjo,2010, Listrik Sel Surya sebagai Energi Alternatif, Surabaya,Jawa Pos .

Saiful Manan, 2011,“ Energi Matahari, Sumber Energi Alternatif Yang Effisien, Handal Dan Ramah Lingkungan Di Indonesia ",Semarang,Universitas Diponogoro.

Anonymus, 2010, energy matahari, tersedia pada http://www.greenpeace.org/seasia/id/_campaigns/perubahan-iklimglobal/Energi-Bersih/Energi matahari. 15 maret 2012. Diakses pada tanggal 13 September 2011

Anonymus, 2011, Pemanfaatan energy matahari, Tersedia pada http://tambangnews.com/serba-serbi/opini/2453-pemanfaatan-energimatahari.html, Diakses pada tanggal 10 September 2011. 